\title{
Pediatric HIV-1-Specific Cytotoxic T-Lymphocyte Responses Suggesting Ongoing Viral Replication Despite Combination Antiretroviral Therapy
}

\author{
NATASCHA CHING, OTTO O. YANG, JAIME G. DEVILLE, KARIN NIELSEN-SAINES, BONNIE J. ANK, \\ MYUNG-SHIN SIM, AND YVONNE J. BRYSON
}

Department of Pediatrics [N.C., J.G.D., K.N.-S., B.J.A., M.S.S., Y.J.B.], Division of Pediatric Infectious Diseases, David Geffen School of Medicine at UCLA and Mattel Children's Hospital at UCLA, Los Angeles, California 90095; Department of Medicine [O.O.Y.], Division of Infectious Diseases and Department of Microbiology, Immunology, and Molecular Genetics, David Geffen School of Medicine at UCLA, Los Angeles, California 90095

\begin{abstract}
Human immunodeficiency virus-1 (HIV-1)-specific cytotoxic T-lymphocyte (CTL) responses are common in infected adults and usually exhibit rapid decay after combination antiretroviral therapy (ART). CTLs develop later in the first year of life, and the fate of HIV-1-specific responses in perinatally infected children after ART is less well described. HIV-1-specific CTL responses were measured in 17 perinatally infected children and adolescents (ages 3-20 y) receiving combination ART. Seven had prolonged viral suppression $(<400$ copies $/ \mathrm{mL})$ for $2.5-5.3 \mathrm{y}$ and 10 had persistent viremia (median, 77,550 copies/mL). HIV-1-specific CTL responses were tested by interferon (IFN)- $\gamma$ enzyme-linked immunospot (ELISpot) assays using 53 overlapping peptide pools spanning the entire HIV-1 proteome. HIV-1-specific CTL responses were detected in 14 of 17 individuals. Responses to one to four viral proteins were found in eight of 10 individuals with persistent viremia and six of seven with prolonged viral suppression. The magnitude and breadth of CTL responses were similar between groups. HIV-1-specific CTL responses were present in the majority of perinatally infected subjects, irrespective of viremia at evaluation. Because ART-treated infected adults usually have rapid decay of responses, these data suggest viral replication below the limits of detection is more persistent in combination ART-treated perinatally infected pediatric subjects. The long-term clinical implications of these findings remain to be determined. (Pediatr Res 61: 692-697, 2007)
\end{abstract}

$\mathrm{P}_{\mathrm{e}}^{\mathrm{r}}$ revious studies of HIV-1-infected infants have shown either the presence or absence of HIV-1 RNA at birth, and the magnitude and duration of early viremia are predictive of the long-term clinical outcome $(1,2)$. The long-term survivors of perinatal HIV-1 infection are a special group of chronically infected children and adolescents critical to enhanced understanding of perinatal HIV-1 infection. As in HIV-1-infected

Received October 11, 2006; accepted February 1, 2007

A portion of this work was presented at the 2003 Conference on Retroviruses and Opportunistic Infections, San Francisco, CA.

Correspondence: Natascha Ching, M.D., Pediatric Infectious Diseases, David Geffen School of Medicine at UCLA, Mattel Children's Hospital at UCLA, 10833 Le Conte Avenue, 22-442 MDCC, Los Angeles, CA 90095; e-mail: nching@mednet.ucla.edu

N.C. was a recipient of the Pediatric Infectious Diseases Society Fellowship and the Glaser Pediatric Research Network Clinical Investigator Fellowship Award. Research was supported in part by grants from NIH U01 AI027550, University of California, Los Angeles General Clinical Research Center M01-RR00865 and 5R21 HD37593-02 (Y.J.B.) and NIH ROI AI043203 (O.O.Y.)

DOI: $10.1203 /$ pdr.0b013e31805365ef adults, combination ART can reduce morbidity and mortality through reduction of viral replication and preservation of $\mathrm{CD}^{+}{ }^{\mathrm{T}}$ lymphocytes in vivo.

Virus-specific $\mathrm{CD}^{+} \mathrm{T}$ lymphocytes or cytotoxic $\mathrm{T}$ lymphocytes (CTLs) represent a key immune response in HIV-1 infection. Strong HIV-1-specific CTL responses have been described to correlate with decreased viremia at the end of primary infection in adults (3-5); these responses persist throughout the chronic phase of infection and usually wane in late-stage disease, suggesting a role for controlling viremia. Experimental depletion of CTLs in the simian immunodeficiency virus (SIV) macaque model results in massive increases in viremia $(6-8)$, further demonstrating their importance. As an arm of adaptive immunity, the expansion and maintenance of CTL are a response to antigen, which drives CTL proliferation. Intracellular antigens are processed via the proteasome pathway for presentation by cell surface human leukocyte antigen (HLA) class I for CTL T-cell receptor binding and consequent signaling for cytolysis, cytokine release, and proliferation. In the course of naturally cleared infections such as influenza and infectious mononucleosis, virus-specific CTL responses wane rapidly to leave low frequencies of resting memory cells. Although HIV-1 infection is generally persistent, this process of natural CTL decay is recapitulated in successful combination ART in HIV-1infected adults. Pharmacologic reduction of viremia to undetectable levels is accompanied by loss of activated HIV-1specific CTLs, which decay to low levels of resting memory cells $(9,10)$.

In contrast to infected adults, CTL responses in perinatally HIV-1-infected individuals are less fully described. Infants have reduced immunocompetence to launch effective antiviral CTL responses and appear to have limited HIV-1-specific CTL responses in the first 3-6 mo of life (11-14). This lack of protective CTL due to immunologic immaturity may contribute to the higher levels of plasma viremia in contrast to

\footnotetext{
Abbreviations: ART, antiretroviral therapy; CR, complete responder; CTL, cytotoxic T lymphocyte; ELISpot, enzyme-linked immunospot; Gag, groupspecific antigen gene; ICR, incomplete responder; Pol, polymerase; Nef, negative regulatory factor; SFC, spot-forming cell
} 
adults. Consistent with this hypothesis is the finding that attenuated SIV yields protective immunity and no disease in adult macaques, but can cause acquired immunodeficiency syndrome (AIDS) in neonatal macaques. After this early period of unresponsiveness in HIV-1-infected humans, however, CTL responses develop and appear to have similar targeting as adults $(15,16)$. However, the lack of correlation of currently available CTL measurements to in vivo antiviral efficacy makes it impossible to assess whether these responses are functionally equivalent to those in adults.

Early initiation of combination ART in infants can suppress viremia, prevent or delay immunodeficiency, and generally dampen HIV-1-specific immune responses. Young infants may become HIV-1-seronegative and have decreased CTL responses if treated with combination ART before 3 mo of age (17). The data from adult-infected persons predict waning of HIV-1-specific CTL responses in the setting of combination ART suppression of viremia due to loss of the antigenic stimulation required for effector CTL expansion and persistence. In contrast to infants and adults, the fate of HIV-1specific responses in perinatally infected children and adolescents after combination ART is less well described. Our hypothesis is that HIV-1 CTL responses vary with the degree of viral suppression in perinatally HIV-1-infected children and adolescents. Here we evaluate the HIV-1-specific CTL responses in a cross-sectional study of chronically infected children and adolescents perinatally infected with HIV-1.

\section{MATERIALS AND METHODS}

Perinatally HIV-1-infected subjects. Seventeen perinatally HIV-1infected children and adolescents attending the Care 4 Families Clinic at Mattel Children's Hospital at the University of California, Los Angeles (UCLA) were evaluated after provision of informed consent under a UCLA Institutional Review Board-approved protocol. All subjects received antiretroviral drugs such as nucleoside reverse transcriptase inhibitors, nonnucleoside reverse transcriptase inhibitors, or protease inhibitors (combination ART) as indicated in Table 1 . In addition, all patients had monitoring of clinical parameters such as T-cell subsets and plasma viremia under the care of their physicians. Ten patients had at least two consecutive HIV-1 RNA values $\geq 400$ copies HIV-1 RNA/mL within 2 y of evaluation, and will be referred to as incomplete responders (ICRs). The remainder $(n=7)$ will be referred to as complete responders (CRs).

Plasma HIV-1 RNA monitoring. The Roche Amplicor HIV-1 Monitor Test, v1.5 (Roche Molecular Diagnostics, Indianapolis, IN) was used to monitor quantitative plasma viremia. The lower limit of detection was 400 copies HIV-1 RNA/mL for the regular assay and 50 copies HIV-1 RNA/mL for the ultrasensitive assay. In earlier specimens, patients were evaluated with regular HIV-1 RNA monitoring assay, but when the ultrasensitive assay became available, the lower limit of plasma viremia was monitored at $<50$ copies HIV-1 RNA $/ \mathrm{mL}$. If results were below the level of detection, half of the assay cutoff was used for data calculation.

Measurement of HIV-1-specific CTL responses. HIV-1-specific CTL responses were assayed by IFN- $\gamma$ ELISpot assays using a previously described protocol $(18,19)$. In brief, polyclonally expanded $\mathrm{CD}^{+} \mathrm{T}$ lymphocytes were derived from heparinized peripheral blood mononuclear cells (PBMCs) (fresh or cryopreserved). These were screened using standard ELISpot assays employing overlapping 15-mer peptides spanning the entire HIV-1 proteome (clade B consensus sequences) obtained through the AIDS Research and Reference Reagent Program, Division of AIDS, National Institute of Allergy and Infectious Diseases, National Institutes of Health (20) in 53 pools of 12-16 peptides. Positive HIV-1-specific ELISpot responses were defined as those $>100$ spot-forming cells (SFCs) $/ 10^{6} \mathrm{CD}^{+} \mathrm{T}$ cells and

Table 1. Patient characteristics

\begin{tabular}{|c|c|c|c|c|c|c|c|c|}
\hline Subject & Age, y & Sex & $\begin{array}{l}\text { HIV RNA } \\
\text { (copies/mL) }\end{array}$ & $\mathrm{CD} 4, \%$ & $\begin{array}{l}\text { CD4 Abs } \\
\left.\text { (cells } / \mathrm{mm}^{3}\right)\end{array}$ & $\mathrm{CD} 8, \%$ & $\begin{array}{l}\text { CD8 Abs } \\
\left.\text { (cells } / \mathrm{mm}^{3}\right)\end{array}$ & Combination ART \\
\hline \multicolumn{9}{|l|}{$\mathrm{CR}(n=7)$} \\
\hline $\mathrm{A}$ & 6.8 & M & Undetectable & 35 & 955 & 29 & 780 & NFV, D4T, DDI \\
\hline $\mathrm{C}$ & 20.3 & M & Undetectable & 21 & 502 & 25 & 572 & NFV, D4T, 3TC \\
\hline $\mathrm{D}$ & 13.4 & $\mathrm{~F}$ & Undetectable & 34 & 1352 & 27 & 1073 & D4T, EFV, NFV \\
\hline $\mathrm{E}$ & 12.1 & M & Undetectable & 35 & 781 & 40 & 893 & AZT/3TC, NFV \\
\hline Median & 14.4 & & & 34 & 781 & 32 & 780 & \\
\hline Range & $6.8-20.3$ & & & $21-37$ & $314-1352$ & $25-40$ & $296-1073$ & \\
\hline \multicolumn{9}{|c|}{$\operatorname{ICR}(n=10)$} \\
\hline $\mathrm{H}$ & 6.6 & M & 70,232 & 15 & 545 & 59 & 2232 & AZT, 3TC, AMP, RTV \\
\hline I & 7.7 & $\mathrm{~F}$ & 1,261 & 33 & 1309 & 39 & 1551 & D4T, 3TC, NVP \\
\hline $\mathrm{J}$ & 14.5 & M & 426 & 20 & 269 & 49 & 670 & $\mathrm{ABC}, 3 \mathrm{TC}, \mathrm{LPV} / \mathrm{r}$ \\
\hline $\mathrm{O}$ & 3.1 & M & 750,000 & 26 & 811 & 30 & 1052 & $\mathrm{AZT}, 3 \mathrm{TC}, \mathrm{LPV} / \mathrm{r}$ \\
\hline $\mathrm{P}$ & 12.1 & M & Undetectable & 37 & 859 & 39 & 909 & EFV, FTC, TNF \\
\hline Q & 9.7 & M & 84,867 & 20 & 475 & 57 & 1354 & AMP, RTV, EFV, D4T \\
\hline Median & 9.5 & & 36,001 & 30 & 678 & 42 & 981 & \\
\hline Range & $3.1-16.5$ & & Undetectable to 750,000 & $1-45$ & $3-1754$ & $20-59$ & $58-2417$ & \\
\hline \multicolumn{9}{|c|}{ All $(n=10)$} \\
\hline Median & 12.1 & & 200 & 34 & 781 & 39 & 893 & \\
\hline Range & $3.1-20.3$ & & Undetectable to 750,000 & $1-45$ & $3-1754$ & $20-59$ & $58-2417$ & \\
\hline
\end{tabular}

F, female; M, male; abs, absolute count; ZDV or AZT, zidovudine; 3TC, lamivudine; D4T, stavudine; DDI, didanosine; NVP, nevirapine; NFV, nelfinavir; EFV, efavirenz; ABC, abacavir; RTV, ritonavir; LPV/r, lopinavir/ritonavir; AMP, amprenavir; T-20, enfuvirtide; TNF, tenofovir; SQV; saquinavir; FTC, emtricitabine. HIV RNA (copies HIV-1 RNA/mL), CD4 ${ }^{+}$and $\mathrm{CD} 8^{+}$absolute count. For the lower limit of detection, half of the assay cutoff was used for calculation. Subject $\mathrm{J}$ had viral suppression for $6 \mathrm{y}$, followed by 3 mo of viremia due to nonadherence. After a switch of combination ART, he had $1 \mathrm{y}$ of undetectable viremia before evaluation. Subject P started a new regimen 3 mo before evaluation. 
at least 3 SDs over background determined using triplicate no peptide controls. For those responses that were below the level of detection, half of the limit of detection was used for data calculation. The HIV-1 viral genes evaluated were group-specific antigen gene (Gag), polymerase (Pol), envelope (Env), negative regulatory factor (Nef), trans-activator of transcription (Tat), regulator of virion $(\mathrm{Rev})$, viral protein $\mathrm{R}(\mathrm{Vpr})$, viral protein $\mathrm{U}(\mathrm{Vpu})$, and viral infectivity factor (Vif).

Statistical analysis. Continuous variables were analyzed with means, SDs, 95\% confidence intervals (CIs), medians, and ranges. Means were compared using $t$ tests. Data with non-normal distributions was assessed using Wilcoxon rank sum tests. HIV-1-specific ELISpot responses were log transformed. Analysis was performed with JMP version 5.1 and SAS software release 8.02 (SAS Inc., Cary, NC).

\section{RESULTS}

Study participants. We studied 17 perinatally HIV-1infected children and adolescents on combination ART. The median age of all participants at HIV-1-specific CTL evaluation was $12.1 \mathrm{y}$ of age (range, 3.1-20.3 y). Overall, subjects had received combination ART for a median duration of $5.3 \mathrm{y}$ (range, 1.5-8 y). CRs received combination ART for a median of 5.3 y (range, 2.9-6.6 y) and had undetectable viremia for a median of $4.3 \mathrm{y}$ (range, 2.5-5.3 y), whereas ICRs were treated for a median of $5.3 \mathrm{y}$ (range, 1.5-8.0 y). Our patient population had severe immunosuppression and clinical disease as defined by Centers for Disease Control and Prevention (CDC) Classification (21). At nadir, 53\% of patients had symptomatic infection (CDC Class C), $41 \%$ had CDC Class B symptoms and one patient had CDC Class A symptoms (6\%). Comparing the groups, $43 \%$ of $\mathrm{CR}$ had CDC Class C clinical disease compared with $60 \%$ of ICRs; $43 \%$ of CRs and $40 \%$ of ICRs had CDC Class B symptoms, but only $14 \%$ of CRs were in Class A. No ICR had CDC Class A symptoms. The lowest level of immunosuppression ever achieved by subjects was CDC immune category 3 in 70\%, CDC immune category 2 in $12 \%$, and CDC immune category 1 in $18 \%$ of patients. At the time of evaluation, clinical parameters remained comparable in the CR and ICR groups, except for the presence or absence of recent viremia (Table 1).

HIV-1-specific CTL responses are present in both CR and ICR groups. To determine whether suppression of detectable viremia by combination ART had an impact on the frequency of HIV-1-specific CTL responses in perinatally infected subjects, these participants were screened using IFN- $\gamma$ ELISpot assays for responding $\mathrm{CD} 8^{+} \mathrm{T}$ lymphocytes (Fig. 1). As might be expected due to the persistence of antigen (as reflected by ongoing viremia), the ICR group had detectable CTL responses in eight of $10(80 \%)$ persons, recognizing a mean of 2.0 viral proteins. Screening of the CRs, however, also demonstrated that the majority had detectable CTL responses against HIV-1, six of seven (86\%) recognizing a mean of 1.57 proteins. These data suggest that loss of detectable viremia after combination ART does not result in complete decay of CTL responses as in infected adults.

The HIV-1-specific CTL responses in ICR and CR groups are similar in magnitude and breadth. To assess whether the degree of treatment response had an impact on the quantity of HIV-1-specific CTLs, the responses between groups were compared for their magnitude and breadth of HIV-1 targeting (Fig. $2 A$ and $B$ ). The total magnitude of HIV-1-specific CTLs
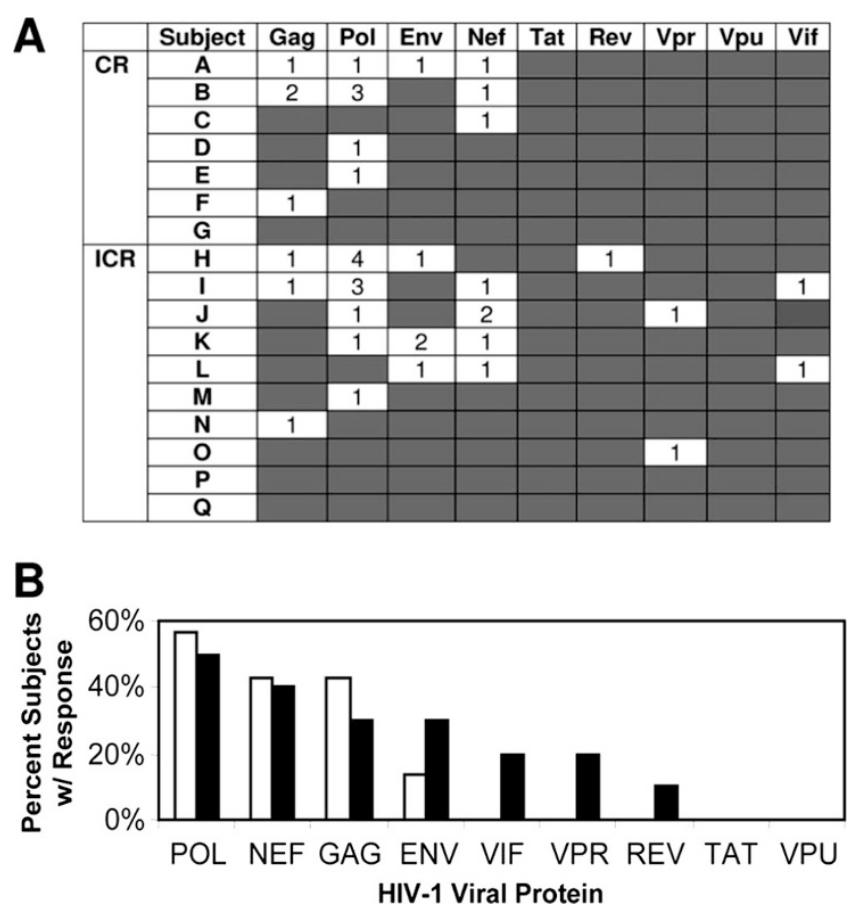

Figure 1. (A) HIV-1-specific CTL responses. Subjects are categorized according to virological response to combination ART. HIV-1-specific CTL responses to viral proteins are listed under each column; numbers indicate the number of viral peptide pools detected. (B) HIV-1-specific CTL responses according to virological response to combination ART. Pol, Nef, and Gag were the most frequent responses detected among all subjects. HIV-1 viral proteins are presented on the $x$ axis from the most frequently recognized to least recognized. CRs $(\square)$, ICRs $(\boldsymbol{\square})$. There was no significant difference between the CR and ICR responses to Pol, Nef, Gag, Env, Vif, Vpr, or Rev by Fisher's exact test.

in the ICR group ranged from 50 to $4825 \mathrm{SFC} / 10^{6} \mathrm{CD}^{+} \mathrm{T}$ lymphocytes [mean, $1120.5 \pm 1493.0$ (95\% CI: $52.7-$ 2188.3)], and the breadth (as reflected by the number of recognized peptide pools of the 53 screened) ranged from 0 to 7 (mean, $2.7 \pm 2.5$ ). In comparison, the magnitude and breadth of HIV-1-specific CTLs in the CR group were similar. The magnitude ranged from 50 to $3220 \mathrm{SFC} / 10^{6} \mathrm{CD}^{+} \mathrm{T}$ lymphocytes [mean $786.4 \pm 1145.6$ (95\% CI: $0-1845.0)$ ], and the breadth ranged from 0 to 6 recognized peptide pools [mean CRs, $2 \pm 2.16$ (95\% CI: 0.002-4.0)]. Thus, the CTL responses in these perinatally infected subjects were quantitatively similar regardless of viremia suppression above or below the limits of detection by combination ART.
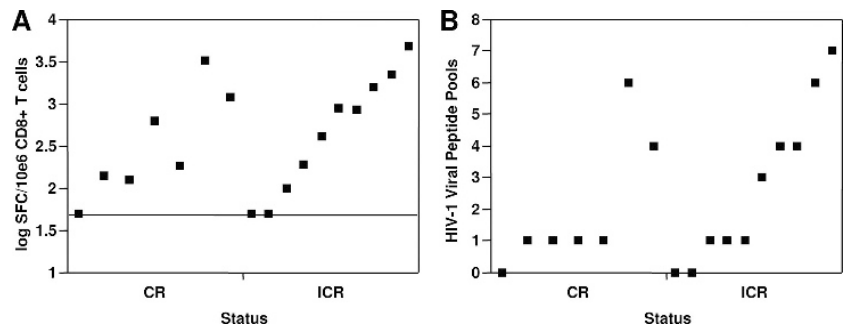

Figure 2. HIV-1-specific CTL targeting according to virological response. Magnitude and breadth of HIV-1-specific CTL targeting according to log $\mathrm{SFC} / 10^{6} \mathrm{CD} 8+\mathrm{T}$ cells $(A)$ and HIV-1 viral peptides $(B)$. The solid line (log 1.7) represents the lower limit of detection for $\log \mathrm{SFC} / 10^{6} \mathrm{CD}^{+} \mathrm{T}$ cells (midpoint used for calculations). 


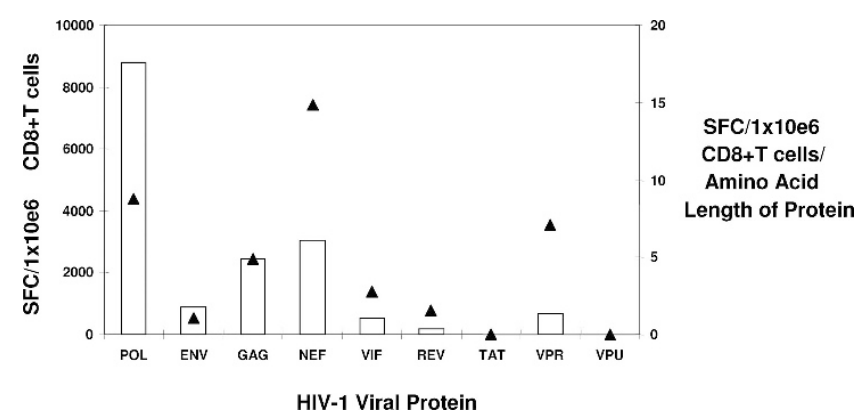

Figure 3. HIV-1-specific CTL targeting adjusted according to amino acid length of viral protein. Columns represent the total magnitude of HIV-1specific CTL responses $\mathrm{SFC} / 10^{6} \mathrm{CD} 8^{+} \mathrm{T}$ cells of each viral protein for all patients; triangles represent the ratio of $\mathrm{SFC} / 10^{6} \mathrm{CD}^{+} \mathrm{T}$ cells/amino acid length of protein. HIV-1 viral proteins are represented on the $x$ axis, from largest protein with the greatest number of amino acids to least (left to right).

HIV-1-specific CTL responses in ICR and CR groups have similar viral targeting. HIV-1-specific CTL responses to individual viral proteins were detected in the majority of patients, 14 of 17 (82\%), as displayed in Figure 1. The most commonly recognized HIV-1 viral protein in all subjects was to Pol in nine of 17 (53\%), followed by Nef in seven (41\%) and Gag in six (35\%). There were no detectable responses to Tat or Vpu in any subjects. Considering the magnitude of HIV-1-specific CTL responses versus the size of the targeted viral proteins, the density of targeting varied, as seen in Figure 3. The magnitude of responses was normalized by calculating the density of target proteins based on the amino acid length for each HIV-1 viral protein. Overall, CR and ICR had similar targeting, with Nef and Pol being the most densely targeted viral proteins.

\section{DISCUSSION}

Studies in adults have demonstrated vigorous HIV-1specific CTL responses that develop at the latter stage of primary infection and persist throughout chronic infection. These responses are driven by the persistence of viral antigen. Clearance of antigen after suppressive combination ART has been shown to interrupt this process, with decay of CTL responses to low memory levels in adults $(9,10,22)$. Broad HIV-1-specific CTL responses have been detected in acutely and chronically infected adults, but no correlation was determined between $\mathrm{CD}^{+} \mathrm{T}$ cell responses and viremia (23). Fewer data about treated pediatric subjects are available. Perinatally infected children appear to have limited CTL responses in the first 3-6 mo of life $(11,13,14,24)$, but then develop responses similar to those seen in adults (16,25-29).

In contrast to treated adults, our data demonstrate persisting HIV-1-specific CTL responses in the majority of perinatally infected subjects on combination ART, with similar magnitude and breadth regardless of viremic suppression on treatment. These findings are different from our original hypothesis. Interestingly, we found that even among patients with highly suppressed viremia, HIV-1-specific CTL responses were still present in this group of long-term survivors. These results agree with previous reports of CTL responses detected in older pediatric subjects on combination ART (16,26-31).
However, some investigators have found a correlation between CD ${ }^{+}$T-cell responses and viremia in those on combination ART $(25,26,29)$ and greater CTL responses were in children with persistent viremia after treatment $(16,27,30)$. Our findings are similar to the CTL responses found in subjects with both detectable and undetectable viremia except for their finding of the significantly lower response noted in subjects with viral suppression and greater overall magnitude in CTL responses in both groups (16). Because CTL proliferation and persistence are driven by antigen, these findings suggest that persistence of viral replication is more common in these perinatally infected subjects who started combination ART later in life compared with adults with primary infection. The reason for this discrepancy compared with treated adults is unclear. However, given the nature of this cross-sectional study, these CTL responses are a measurement of one point in time for a specific group of pediatric patients.

Our current study differs from previous studies in the methodology to assess HIV-1-specific CTL responses. We evaluated the entire HIV-1 proteome using 53 overlapping peptide pools with clade $\mathrm{B}$ consensus sequences from National Institutes of Health (20) as did Feeney et al. (16). The findings in that study were different from ours as previously mentioned. Previous investigators have used recombinant vaccinia vectors expressing single specific viral proteins but not all HIV-1 proteins at once $(15,17,25-28,30,31)$ or tetrameric complexes $(17,29,30)$. Most authors have measured IFN- $\gamma$ by ELISpot assays, as we did, with the exception of those who used chromium release assays to measure CTL responses $(15,17,31)$.

A major difference between adults and perinatally infected children is that adults are infected after immunologic maturity, whereas children face infection during immunologic maturation. This raises the possibility that HIV-1 infection fundamentally alters some developmental property of the immune system, such as immune regulation (e.g. dysregulation causing inappropriate immune activation that favors ongoing viral replication) or effector competence to contribute to containment of viral replication during drug treatment. Interestingly, very early treatment of infected infants can yield highly effective suppression of viremia that can prevent antibody responses (17), making the latter possibility less likely. Additional evidence that very early treatment is more effective than later treatment for suppressing viremia in these patients comes from the observation that infants treated early $(<3 \mathrm{mo})$ with combination ART have a higher rate of sustained viral suppression after 4 y (32). Moreover, another cohort of perinatally infected subjects who started combination ART later in life, as in our study, also demonstrated persisting HIV-1specific CTL responses (28).

In addition, it is well established that viremia set points in children are higher than adults, and achieving undetectable viremia in perinatally infected subjects is only $56 \%$ after 12 mo (33) and 52\% and 18\% successful after 12 and 24 mo of treatment, respectively (34), which is much lower than adults. Pediatric subjects on combination ART have been reported to reach undetectable levels of viremia $<400$ and $<50$ copies HIV-1 RNA/mL by median of 4 and 20 wk, respectively (35). 
Of those patients who reach undetectable $(<400$ copies HIV-1 $\mathrm{RNA} / \mathrm{mL}$ ), $83 \%$ remained suppressed for 6 mo.

It is known that a "latent reservoir" of replication competent virus allows HIV-1 persistence even in the setting of suppressive combination ART $(36,37)$. This reservoir serves as a source of continued low-grade viral replication even in adults with treatment and undetectable viremia. Supersensitive methods reveal persisting viral transcription in these persons (38). The existence of the latent reservoir in perinatally infected subjects from our group (39) and other cohorts (40) also has been demonstrated. Thus, the continuing presence of latent viral reservoirs even among children with highly suppressed viremia may potentially be the reason why CTL responses are preserved.

In summary, our data indicate that HIV-1-specific CTL responses persisted in our group of perinatally infected children and adolescents, indicating persistence of viral replication. This suggests that alteration of immunity due to infection before immunologic maturity renders a change that increases basal HIV-1 replication and/or reduces clearance of HIV-1 during combination ART. Further delineation of the HIV-1specific CTL responses in relationship to disease progression and control of viremia should be investigated in HIV-1infected pediatric subjects on combination ART. Our studies are limited in a cross-sectional study, but further prospective evaluation is warranted to investigate HIV-1-specific CTL responses influenced by timing of ART, CD4 recovery and function, latent reservoirs, and virological suppression.

Acknowledgments. The authors thank the HIV-1-infected children and families who participated in this study.

\section{REFERENCES}

1. Dickover RE, Dillon M, Leung KM, Krogstad P, Plaeger S, Kwok S, Christopherson C, Deveikis A, Keller M, Stiehm ER, Bryson YJ 1998 Early prognostic indicators in primary perinatal human immunodeficiency virus type 1 infection: importance of viral RNA and the timing of transmission on long-term outcome. J Infect Dis 178:375-387

2. Shearer WT, Quinn TC, LaRussa P, Lew JF, Mofenson L, Almy S, Rich K, Handelsman E, Diaz C, Pagano M, Smeriglio V, Kalish LA 1997 Viral load and disease progression in infants infected with human immunodeficiency virus type 1 . Women and Infants Transmission Study Group. N Engl J Med 336:1337-1342

3. Borrow P, Lewicki H, Hahn BH, Shaw GM, Oldstone MB 1994 Virus-specific CD8 + cytotoxic T-lymphocyte activity associated with control of viremia in primary human immunodeficiency virus type 1 infection. J Virol 68:6103-6110

4. Koup RA, Safrit JT, Cao Y, Andrews CA, McLeod G, Borkowsky W, Farthing C, Ho DD 1994 Temporal association of cellular immune responses with the initial control of viremia in primary human immunodeficiency virus type 1 syndrome. J Virol 68:4650-4655

5. Musey L, Hughes J, Schacker T, Shea T, Corey L, McElrath MJ 1997 CytotoxicT-cell responses, viral load, and disease progression in early human immunodeficiency virus type 1 infection. N Engl J Med 337:1267-1274

6. Jin X, Bauer DE, Tuttleton SE, Lewin S, Gettie A, Blanchard J, Irwin CE, Safrit JT, Mittler J, Weinberger L, Kostrikis LG, Zhang L, Perelson AS, Ho DD 1999 Dramatic rise in plasma viremia after $\mathrm{CD} 8(+) \mathrm{T}$ cell depletion in simian immunodeficiency virus-infected macaques. J Exp Med 189:991-998

7. Matano T, Shibata R, Siemon C, Connors M, Lane HC, Martin MA 1998 Administration of an anti-CD8 monoclonal antibody interferes with the clearance of chimeric simian/human immunodeficiency virus during primary infections of rhesus macaques. J Virol 72:164-169

8. Schmitz JE, Kuroda MJ, Santra S, Sasseville VG, Simon MA, Lifton MA, Racz P, Tenner-Racz K, Dalesandro M, Scallon BJ, Ghrayeb J, Forman MA, Montefiori DC, Rieber EP, Letvin NL, Reimann KA 1999 Control of viremia in simian immunodeficiency virus infection by CD8+ lymphocytes. Science 283:857-860

9. Kalams SA, Goulder PJ, Shea AK, Jones NG, Trocha AK, Ogg GS, Walker BD 1999 Levels of human immunodeficiency virus type 1-specific cytotoxic T-lymphocyte effector and memory responses decline after suppression of viremia with highly active antiretroviral therapy. J Virol 73:6721-6728
10. Ogg GS, Jin X, Bonhoeffer S, Moss P, Nowak MA, Monard S, Segal JP, Cao Y, Rowland-Jones SL, Hurley A, Markowitz M, Ho DD, McMichael AJ, Nixon DF 1999 Decay kinetics of human immunodeficiency virus-specific effector cytotoxic T lymphocytes after combination antiretroviral therapy. J Virol 73:797-800

11. Luzuriaga K, Holmes D, Hereema A, Wong J, Panicali DL, Sullivan JL 1995 HIV-1-specific cytotoxic T lymphocyte responses in the first year of life. J Immunol 154:433-443

12. Luzuriaga K, Koup RA, Pikora CA, Brettler DB, Sullivan JL 1991 Deficient human immunodeficiency virus type 1 -specific cytotoxic $\mathrm{T}$ cell responses in vertically infected children. J Pediatr 119:230-236

13. Pikora CA, Sullivan JL, Panicali D, Luzuriaga K 1997 Early HIV-1 envelopespecific cytotoxic T lymphocyte responses in vertically infected infants. J Exp Med 185:1153-1161

14. Buseyne F, Burgard M, Teglas JP, Bui E, Rouzioux C, Mayaux MJ, Blanche S, Riviere Y 1998 Early HIV-specific cytotoxic T lymphocytes and disease progression in children born to HIV-infected mothers. AIDS Res Hum Retroviruses 14:14351444

15. Buseyne F, Blanche S, Schmitt D, Griscelli C, Riviere Y 1993 Detection of HIV-specific cell-mediated cytotoxicity in the peripheral blood from infected children. J Immunol 150:3569-3581

16. Feeney ME, Roosevelt KA, Tang Y, Pfafferott KJ, McIntosh K, Burchett SK, Mao C, Walker BD, Goulder PJ 2003 Comprehensive screening reveals strong and broadly directed human immunodeficiency virus type 1-specific CD8 responses in perinatally infected children. J Virol 77:7492-7501

17. Luzuriaga K, McManus M, Catalina M, Mayack S, Sharkey M, Stevenson M, Sullivan JL 2000 Early therapy of vertical human immunodeficiency virus type 1 (HIV-1) infection: control of viral replication and absence of persistent HIV-1specific immune responses. J Virol 74:6984-6991

18. Ibarrondo FJ, Anton PA, Fuerst M, Ng HL, Wong JT, Matud J, Elliott J, Shih R, Hausner MA, Price C, Hultin LE, Hultin PM, Jamieson BD, Yang OO 2005 Parallel human immunodeficiency virus type 1-specific CD8 + T-lymphocyte responses in blood and mucosa during chronic infection. J Virol 79:4289-4297

19. Yang OO, Daar ES, Jamieson BD, Balamurugan A, Smith DM, Pitt JA, Petropoulos CJ, Richman DD, Little SJ, Brown AJ 2005 Human immunodeficiency virus type 1 clade B superinfection: evidence for differential immune containment of distinct clade B strains. J Virol 79:860-868

20. NIH AIDS Research and Reference Reagent Program, Division of AIDS, NIAID, $\mathrm{NIH}$

21. CDC 1994 Revised classification system for human immunodeficiency virus infection in children less than 13 years of age. MMWR Recomm Rep 43:1-10

22. Rinaldo CR Jr, Huang XL, Fan Z, Margolick JB, Borowski L, Hoji A, Kalinyak C, McMahon DK, Riddler SA, Hildebrand WH, Day RB, Mellors JW 2000 Anti-human immunodeficiency virus type 1 (HIV-1) CD8(+) T-lymphocyte reactivity during combination antiretroviral therapy in HIV-1-infected patients with advanced immunodeficiency. J Virol 74:4127-4138

23. Addo MM, Yu XG, Rathod A, Cohen D, Eldridge RL, Strick D, Johnston MN, Corcoran C, Wurcel AG, Fitzpatrick CA, Feeney ME, Rodriguez WR, Basgoz N, Draenert R, Stone DR, Brander C, Goulder PJ, Rosenberg ES, Altfeld M, Walker BD 2003 Comprehensive epitope analysis of human immunodeficiency virus type 1 (HIV-1)-specific T-cell responses directed against the entire expressed HIV-1 genome demonstrate broadly directed responses, but no correlation to viral load. J Virol 77:2081-2092

24. Scott ZA, Chadwick EG, Gibson LL, Catalina MD, McManus MM, Yogev R, Palumbo P, Sullivan JL, Britto P, Gay H, Luzuriaga K 2001 Infrequent detection of HIV-1-specific, but not cytomegalovirus-specific, CD8(+) T cell responses in young HIV-1-infected infants. J Immunol 167:7134-7140

25. Buseyne F, Scott-Algara D, Bellal N, Burgard M, Rouzioux C, Blanche S, Riviere Y 2005 The frequency of HIV-specific interferon- gamma -producing CD8 T cells is associated with both age and level of antigenic stimulation in HIV-1-infected children. J Infect Dis 192:1781-1786

26. Borkowsky W, Zhan MX, Chen SH, Ilmet T, Kaul A, Chandwani S, Rigaud M, Essajee S, Gruber C, Freedman A, Krasinski K 2004 Correlation between HIVSpecific CD8 cell production of interferon- gamma and plasma levels of HIV RNA in perinatally infected pediatric populations. J Infect Dis 190:722-726

27. Papasavvas E, Sandberg JK, Rutstein R, Moore EC, Mackiewicz A, Thiel B, Pistilli M, June RR, Jordan KA, Gross R, Maino VC, Nixon DF, Montaner LJ 2003 Presence of human immunodeficiency virus-1-specific CD4 and CD8 cellular immune responses in children with full or partial virus suppression. J Infect Dis 188:873-882

28. Spiegel HM, Chandwani R, Sheehy ME, Dobroszycki J, Fennelly G, Wiznia A, Radding J, Rigaud M, Pollack H, Borkowsky W, Rosenberg M, Nixon DF 2000 The impact of early initiation of highly active antiretroviral therapy on the human immunodeficiency virus type 1 -specific CD8 T cell response in children. J Infect Dis 182:88-95

29. Buseyne F, Scott-Algara D, Porrot F, Corre B, Bellal N, Burgard M, Rouzioux C, Blanche S, Riviere Y 2002 Frequencies of ex vivo-activated human immunodeficiency virus type 1-specific gamma-interferon-producing CD8 $+\mathrm{T}$ cells in infected children correlate positively with plasma viral load. J Virol 76:12414-12422

30. Sandberg JK, Fast NM, Jordan KA, Furlan SN, Barbour JD, Fennelly G, Dobroszycki J, Spiegel HM, Wiznia A, Rosenberg MG, Nixon DF 2003 HIV-specific CD8+ $\mathrm{T}$ cell function in children with vertically acquired HIV-1 infection is critically influenced by age and the state of the CD4+ T cell compartment. J Immunol 170:4403-4410

31. McFarland EJ, Harding PA, Striebich CC, MaWhinney S, Kuritzkes DR, Kotzin BL 2002 Clonal CD8 + T cell expansions in peripheral blood from human immunodeficiency virus type 1-infected children. J Infect Dis 186:477-485 
32. Luzuriaga K, McManus M, Mofenson L, Britto P, Graham B, Sullivan JL 2004 A trial of three antiretroviral regimens in HIV-1-infected children. N Engl J Med 350:2471-2480

33. Aboulker JP, Babiker A, Chaix ML, Compagnucci A, Darbyshire J, Debre M, Faye A, Giaquinto C, Gibb DM, Harper L, Saidi Y, Walker AS 2004 Highly active antiretroviral therapy started in infants under 3 months of age: 72-week follow-up for CD4 cell count, viral load and drug resistance outcome. AIDS 18:237-245

34. Faye A, Bertone C, Teglas JP, Chaix ML, Douard D, Firtion G, Thuret I, Dollfus C, Monpoux F, Floch C, Nicolas J, Vilmer E, Rouzioux C, Mayaux MJ, Blanche S 2002 Early multitherapy including a protease inhibitor for human immunodeficiency virus type 1-infected infants. Pediatr Infect Dis J 21:518-525

35. Spector SA, Hsia K, Yong FH, Cabral S, Fenton T, Fletcher CV, McNamara J, Mofenson LM, Starr SE 2000 Patterns of plasma human immunodeficiency virus type 1 RNA response to highly active antiretroviral therapy in infected children. J Infect Dis 182:1769-1773

36. Chun TW, Carruth L, Finzi D, Shen X, DiGiuseppe JA, Taylor H, Hermankova M, Chadwick K, Margolick J, Quinn TC, Kuo YH, Brookmeyer R, Zeiger MA,
Barditch-Crovo P, Siliciano RF 1997 Quantification of latent tissue reservoirs and total body viral load in HIV-1 infection. Nature 387:183-188

37. Finzi D, Blankson J, Siliciano JD, Margolick JB, Chadwick K, Pierson T, Smith K, Lisziewicz J, Lori F, Flexner C, Quinn TC, Chaisson RE, Rosenberg E, Walker B, Gange S, Gallant J, Siliciano RF 1999 Latent infection of CD4+ T cells provides a mechanism for lifelong persistence of HIV-1, even in patients on effective combination therapy. Nat Med 5:512-517

38. Furtado MR, Callaway DS, Phair JP, Kunstman KJ, Stanton JL, Macken CA, Perelson AS, Wolinsky SM 1999 Persistence of HIV-1 transcription in peripheralblood mononuclear cells in patients receiving potent antiretroviral therapy. N Engl J Med 340:1614-1622

39. Equils O, Garratty E, Wei LS, Plaeger S, Tapia M, Deville J, Krogstad P, Sim MS, Nielsen K, Bryson YJ 2000 Recovery of replication-competent virus from CD4 T cell reservoirs and change in coreceptor use in human immunodeficiency virus type 1-infected children responding to highly active antiretroviral therapy. J Infect Dis 182:751-757

40. Persaud D, Pierson T, Ruff C, Finzi D, Chadwick KR, Margolick JB, Ruff A, Hutton N, Ray S, Siliciano RF 2000 A stable latent reservoir for HIV-1 in resting CD4(+) T lymphocytes in infected children. J Clin Invest 105:995-1003 